\title{
A CONSTRUÇÃO DE VALORES AMBIENTAIS EM PRÁTICAS DE LAZER ATRAVÉS DA ESCALADA
}

Recebido em: 11/11/2019

Aprovado em: 08/07/2020

Licença:@) (1) @

Ingrid Olegário Antas ${ }^{1}$

Mateus David Finco ${ }^{2}$

Universidade Federal da Paraíba (UFPB)

João Pessoa - PB - Brasil

RESUMO: Por ser uma prática que vem ganhando muitos adeptos, a escalada segue se destacando e se tornando objeto de estudos acadêmicos na área de Educação Física. O objetivo do estudo é investigar a construção de valores ambientais a partir das experiências através da prática da escalada ao ar livre. Este estudo tem natureza qualitativa, descritiva e transversal. A amostra foi composta por dezesseis sujeitos com idades entre 20 e 40 anos. As variáveis investigadas foram analisadas por um questionário online, com questões sobre a construção de valores ambientais que a prática da escalada pode proporcionar. Os dados foram analisados de forma qualitativa através de análise de conteúdo e apresentados através de gráficos e tabelas comparativas. Concluiu-se nesta pesquisa que existe um satisfatório desenvolvimento de construção de valores ambientais através da prática da escalada, em especial com mudanças nas relações e atitudes diante da natureza, além da promoção de valores sociais, culturais, psicológicos e cognitivos na vida cotidiana dos praticantes.

PALAVRAS-CHAVE: Escalada. Valores Ambientais. Atividades de Lazer.

\section{THE ENVIRONMENTAL VALUES DEVELOPMENT IN LEISURE PRACTICES TROUGH CLIMBING}

ABSTRACT: As a practice that has been gaining many followers, Climbing continues standing out and becoming the object of academic studies in the area of Physical Education. The aim of this study is to investigate the development of environmental from the experiences through the practice of Climbing. This study carried out has a qualitative, descriptive and cross-sectional design. The sample consisted of sixteen participants aged from 20 to 40 years old. The variables investigated were analyzed by an online questionnaire with questions about the development of environmental values Climbing practices can offer. The data were analyzed by a qualitative format through the content

\footnotetext{
${ }^{1}$ Graduada nos cursos de Licenciatura e Bacharelado em Educação Física pela Universidade Federal da Paraíba. Integrante do Grupo de Estudos SPORTSFAN e do Laboratório de Estudos e Pesquisas em Atividades Físicas e Saúde (LEPAFS).

2 Doutor em Informática na Educação pela Universidade Federal do Rio Grande do Sul (UFRGS). Docente da Universidade Federal da Paraíba (UFPB). Líder do Grupo de Estudos SPORTSFAN e vice-coordenador do Laboratório de Estudos e Pesquisas em Atividades Físicas e Saúde (LEPAFS).
} 
analysis and presented by comparative charts and tables. The research identified the relationship between Climbing and the development of values. It was possible to conclude that exists a satisfactory development of environmental values through Climbing practice, specially with changes in the relations and attitudes in the face of the nature, besides the promotion of social, cultural, psychological and cognitive values in the daily life of the practitioners.

KEYWORDS: Climbing. Environmental Values. Leisure Activities.

\section{Introdução}

A prática de esporte de aventura é baseada em práticas corporais, que ocorrem no âmbito do lazer e da competição que inclui a aventura, o risco e as fortes emoções. Estas atividades acontecem no meio natural e desperta em seus praticantes sentimentos de auto realização e consequentemente melhoria da qualidade de vida (PAIXÃO, 2018). Ainda conforme o autor, a qualidade de vida melhora com a prática do esporte de aventura, porque o contato com a natureza desperta boas sensações nos indivíduos e ajudam a aliviar o estresse vivido no cotidiano. Há uma série de esportes de aventura, como Rapel, Trilhas, Tirolesa dentre outros, e um dos esportes que vem crescendo o número de adeptos é a escalada.

A escalada, assim como o montanhismo, surgiu há muitos anos, e a principal motivação para sua existência foi à vontade humana de explorar a natureza e alcançar lugares inusitados. Os primeiros aventureiros tiveram como motivação a vontade de conhecer o que estava acima dos seus olhos e as escaladas em montanhas deram início a esta aventura. A segurança para as escaladas foram sendo inseridas com o passar do tempo e, hoje os escaladores contam com uma série de equipamentos como cordas, mosquetões, cadeirinhas, freios, sapatilhas e vestimentas apropriadas para garantir mais segurança na hora da subida. Portanto, a segurança passou a ser uma das preocupações dos escaladores, pois a queda pode levar a lesões graves e até a morte. Desta forma, os praticantes de escalada contam com um escalador guia e outro que faz a segurança, além de técnicas 
realizadas durante a prática (PEREIRA, 2007). Por ser um esporte de aventura derivado do montanhismo, a escalada foi evoluindo com o passar dos anos. O ápice da prática se deu no início da década de 1980, e esta modalidade foi ganhando cada vez mais adeptos e se espalhando por todo o mundo. Atualmente, segundo dados da Federação Internacional de Escalada Esportiva, há mais de 45 países participando regularmente de competições indoor que acontecem em âmbito continental e mundial (BERTUZZI et al., 2011).

No Brasil, a escalada teve início desde o século XX e, um dos marcos históricos da escalada no Brasil foi em 1914 quando umas equipes de escaladores franceses tentaram escalar os 300 metros da rocha Dedo de Deus em Teresópolis no Rio de Janeiro (PEREIRA, 2007). Por ser uma atividade que proporciona prazer, a escalada está presente em muitas programações de lazer e ao mesmo tempo, oferece aos seus praticantes a oportunidade de superar limites e de conhecer pessoas e lugares cheios de histórias. A cada nova escalada os praticantes através de uma prática lúdica e prazerosa têm a oportunidade de estarem mais próximos da natureza, além de obter inúmeros benefícios. Fisicamente o escalador desenvolve habilidades motoras como saltar, equilibrar-se dentre outras e capacidades físicas, como aumento da força, da resistência física, equilíbrio das emoções, coordenação motora e inteligência corporal entre outros benefícios psicológicos, como desenvolvimento da coragem, disposição para enfrentar os desafios, disciplina, força de vontade, aumento da confiança, persistência, concentração, memória e capacidade de visualizar problemas e criar estratégias para superá-los (PEREIRA; PICOLLO, 2013).

Conforme Bertuzzi e Silva (2013) o aumento do número de adeptos das atividades de aventura praticadas em ambiente natural é fruto da vontade do homem de estar mais próximo da natureza, recebendo assim momentos mais prazerosos no seu tempo livre, e 
este aumento no Brasil surgiu a partir do final do século passado. Ainda conforme os autores supracitados o termo "escalada em rocha" é composto por diferentes estilos de ascensões realizadas em paredes rochosas destacando-se os estilos de escalada Boulder, a Esportiva, a Tradicional e o Big Wall.

Entre os tipos de escalada estão o Boulder, que se caracteriza como um tipo de escalada em rocha que é praticado com poucos equipamentos e técnicas de segurança, onde seus praticantes utilizam sapatilhas e sacos específicos que contém carbonato de magnésio para evitar o suor nas mãos e colchões pequenos chamados de Crash Pad que são colocados na base da rocha ou pelos companheiros para amenizar o impacto com o solo no caso da desistência ou queda. Este tipo de escalada é realizada em pequenos blocos de pedras com uma altura inferior a 6 metros, os movimentos são de extrema dificuldade física e habilidade técnica, se tornando necessário que o praticante faça uma sequência de movimentos na rocha tendo que retornar ao ponto inicial caso sofra queda ou haja desistência durante a subida.

Por ser um estilo complexo seus praticantes precisam ter habilidade e força muscular para que consiga efetuar a subida utilizando os membros superiores e inferiores simultaneamente e de forma equilibrada. Neste sentido, a escalada em Boulder é um estilo complexo, pois envolve uma elevada solicitação técnica, com ênfase na força muscular isométrica e na potência muscular dos membros superiores, além da flexibilidade dos membros inferiores (BERTUZZI; SILVA, 2013).

$\mathrm{Na}$ escalada de bloco é possível escalar em uma rocha ou em muro e este tipo de atividade exige treino, força e resistência física. Além destas características o individuo precisa ter coordenação, flexibilidade e equilíbrio, desta forma se faz necessário que os mesmos passem por um treinamento especializado (PEREIRA; PICCOLO, 2013).

A Escalada Esportiva é realizada em pequenas falésias de 50 metros de altura que 
possuem proteções fixadas de forma permanente para segurança do escalador. Este tipo de proteção tem a finalidade de amenizar os riscos de acidentes fatais. As vias utilizadas neste tipo de escalada são bem protegidas através de grampos ou chapeletas e neste tipo de atividade o praticante precisa de força isométrica, da sua potência muscular e resistência dos membros superiores para poder superar as dificuldades técnicas da via. Vale salientar que nesta modalidade de escalada esportiva, o escalador é envolvido por fitas sintéticas e fivelas de ferro chamadas de cadeirinhas anexadas a uma corda dinâmica com ganchos de duralumínio conhecido também como mosquetões (ENNES, 2013). Além disso, a ascensão das rotas é uma característica deste estilo, sendo válida apenas quando o praticante não sofre quedas ao longo da rota e, não utiliza proteções fixas para se apoiar. Neste tipo de escalada destacam-se o On-Sight que ocorre quando o escalador consegue a ascensão sem observar outro escalador ou quando não tem nenhum tipo de informação prévia. Este tipo de escalada é utilizada em rotas das semifinais e finais de competições esportivas indoor. O Red Point, que é feito quando o escalador consegue subir a rota após uma ou mais tentativas e o estilo Hang-Dog utilizado em treinos onde são necessárias demandas físicas e técnicas para uma determinada rota esportiva (BERTUZZI; SILVA, 2013).

$\mathrm{Na}$ escalada esportiva realizada nas rochas, na natureza, apesar de certo controle possibilitado pelo equipamento, não se pode previamente, deduzir sequências motoras, muito menos controlar totalmente os fatores externos, o que exige por parte dos praticantes, bastante treinamento e saúde física e mental. O escalador nesta atividade precisa ter controle emocional e a capacidade de concentração para que os fatores externos não prejudiquem a sua visibilidade e movimento (MARINHO; BRUHS, 2001).

A Escalada Tradicional é praticada em paredes com altura acima de 80 metros e seus praticantes precisam na maioria das vezes fazer longas caminhadas até chegar à base 
da rocha, e as proteções neste tipo de escalada não são fixadas na rocha para causar um menor impacto ambiental. Uma das características dessa modalidade é que os praticantes têm como regra não degradar o meio ambiente e por este motivo as suas proteções são feitas com recursos naturais disponíveis como o lançamento de pontas da rocha com uma fita ou entalando peças metálicas nas deformações rochosas que são retiradas posteriormente. Entre as características destes praticantes de escalada tradicional estão a sua aptidão aeróbia, logística, capacidade de manusear os equipamentos e alguns conhecimentos acerca da meteorologia (PEREIRA, 2007).

O Big Wall é um tipo de escalada realizada em grandes paredes rochosas com altura acima de 600 metros. Os seus praticantes experimentam um isolamento total da sociedade e o resgate neste tipo de atividade é muito difícil. A escalada em Big Wall exige além de autocontrole, logística, capacidade de organização, trabalho em equipe, certa perícia, um bom julgamento das ações e perseverança. Os equipamentos utilizados por estes praticantes são carregados em mochilas de material sintético que chegam a suportar o atrito com a rocha e são chamadas de Haul Bags. Cada Haul Bag pode pesar acima de $30 \mathrm{~kg}$. Entre as habilidades que este tipo de escalada exige dos seus praticantes estão à aptidão aeróbia e a utilização de técnicas de escalada artificiais.

Como alguns trechos na parede não podem ser escalados utilizando-se apenas as mãos, devido à superfície lisa da formação rochosa, os escaladores desenvolveram técnicas e equipamentos utilizados na progressão como o Cliff, peça metálica com o formato similar ao de um anzol de pesca que pode ser colocado sobre uma pequena saliência rochosa (BERTUZZI; SILVA, 2013).

Todos os tipos de escalada proporcionam ao escalador o contato com a natureza e de uma forma ou de outra, estes praticantes já tiveram a oportunidade de explorar lugares e paisagens naturais em algum momento da sua vida. $\mathrm{O}$ aumento de adeptos a este tipo 
de atividade vem crescendo, em especial em práticas de lazer, e uma das maiores preocupações é a conscientização da preservação do meio ambiente durante a atividade da escalada (BAHIA; SAMPAIO, 2007). Além dos benefícios físicos, psicológicos e sociais advindos da prática da escalada, esta prática também desperta em seus praticantes a vontade de manter mais contato com a natureza e consequentemente de passar a preservá-la. Neste sentido por meio do esporte é possível socializar diferentes indivíduos desenvolvendo assim as relações sócio-afetivas, a comunicabilidade e sociabilidade ajustando neste contexto, o homem ao meio que vive, pois a partir das relações sociais o homem passa a interagir com outras culturas e modos de vida ampliando sua identidade cultural e tendo acesso a diferentes ideias e opiniões (BURITI, 2001). Nazari; Gomes; Oliveira (2008) elenca uma série de atitudes e ações para minimizar os impactos na natureza, como permanecer nas trilhas, manter o silêncio, ver e fotografar somente sem coletar ou pegar "recordações", nunca descartar objetos e lixo na natureza e caminhar levemente sem levantar poeira ou pedras.

Além de cuidados com o meio ambiente, durante a prática da escalada os indivíduos experimentam uma gama de emoções, sensações e sentimentos e aprendem a superar obstáculos e a conhecer seus limites. Também permite que os indivíduos desacelerem e experimentem novas sensações, inicialmente tensão, nervosismo e, aos poucos a adrenalina vai tomando espaço. A consciência ambiental é um dos valores mais urgentes a serem desenvolvidos pela sociedade principalmente quando estão à procura de lugares naturais para atividades de lazer. Deste modo, os praticantes de esportes de aventura na natureza têm buscado resgatar os valores de preservação e cuidado com o meio ambiente, tão necessários no contexto atual. Esta reaproximação do ambiente natural em atividades de lazer leva a sociedade a se engajar cada vez mais em tais discussões (BAHIA; SAMPAIO, 2007). 
Em estudos realizados sobre a participação de um grupo de escalada como uma prática de lazer, os pesquisadores Vargas; Silva e Amaral (2015) destacam que a escalada pode ser uma prática central, sendo esta o núcleo de um universo composto pela influência de muitas ações, significados e conflitos. Neste estudo foi apontado que o engajamento a uma atividade específica de lazer não é simplesmente restrita ao seu exercício e tampouco ser explicada apenas através de sua prática central de forma isolada. Neste sentido, a escalada pode abranger diversos elementos que, além da prática física como prática central, pode também envolver o entretenimento e a ludicidade durante as atividades desenvolvidas.

Honorato e Xavier (2013) ilustram que no esporte e no lazer encontram-se possibilidades de experimentação e sensibilização de situações desafiadoras. A vivência de fortes emoções e intensos riscos controlados é identificada, sobretudo, nas práticas denominadas atividades de risco e de aventura, como é caso da escalada. Também os autores apontam que além dos inúmeros benefícios a escalada abarca o de educação para o lazer de aventura, em especial no que permeia o prazer de escalar.

Diante do exposto, foi estabelecida a seguinte pergunta de pesquisa para este estudo: como ocorre a construção de valores ambientais a partir das experiências em escaladas ao ar livre? Percebemos que a necessidade humana em buscar ambientes naturais para fugir do cotidiano das cidades tem levado a sociedade e os praticantes de esportes de aventura a refletir sobre a preservação destes lugares e da sua riqueza natural. Sendo assim, o objetivo geral do presente estudo foi o de investigar a construção de valores ambientais a partir das experiências através da prática da escalada ao ar livre e para tal elencou-se como objetivos específicos: identificar quais valores ambientais são adquiridos pelos praticantes durante a prática da escalada ao ar livre; estabelecer a relação 
entre a prática de escalada e o lazer e analisar se a prática de escalada transforma os valores ambientais de seus praticantes.

Sabe-se que a conscientização humana é fruto da reflexão das atitudes positivas e negativas em relação a sua ação na vida e na natureza, e esta reflexão muitas vezes precisa ser motivada pela ação de diferentes agentes da sociedade. O poder público não está isento desta construção de valores, assim como a educação também não está. Como afirmam Bahia e Sampaio (2007) é preciso que existam ações contínuas de conscientização do meio natural e cultural e, que os praticantes de esportes de aventura sejam efetivamente conscientes da ação positiva que precisam realizar dentro do ambiente natural. Não é apenas uma questão de fugir da sua realidade barulhenta e de se lançar em uma aventura dentro da natureza, mas de querer e desejar manter toda esta riqueza natural preservada para que outras gerações tenham a oportunidade de experimentar as sensações que tais atividades lhe trazem.

Diante disso, Santin (1993) define que a velocidade da vida e a falta de tempo das pessoas nos grandes centros urbanos não permite que os indivíduos parem para repensar os valores. As pessoas estão aceleradas, preocupadas com compromissos, e acabam esquecendo-se de dedicar tempo para si mesmo, e para experimentar a vida sendo, portanto, necessário à inserção do esporte e do lazer para aliviar as tensões do cotidiano e melhorar a qualidade de vida das pessoas.

\section{Métodos e Procedimentos}

A pesquisa é de campo, de natureza qualitativa e descritiva com corte transversal e a amostra foi composta por dezesseis praticantes escalada de ambos os sexos com idade entre 20 e 40 anos de idade. As variáveis investigadas foram analisadas por meio de um questionário online, visto que, nem todos do grupo de praticantes moravam em João 
Pessoa. Os praticantes de escalada responderam a questões sobre a construção de valores que esta modalidade esportiva desperta nos indivíduos que a praticam. Quanto aos procedimentos, no primeiro momento foi feito um contato inicial com um grupo de esportes de aventura do Município de João Pessoa, este grupo realiza diversas modalidades dentro e fora do Município, como Araruna/PB, Bananeiras/PB dentre outros.

Os objetivos da pesquisa foram expostos aos praticantes, e realizado o pedido de autorização para responderem o questionário através do termo livre de consentimento e no segundo momento foram incluídos na pesquisa os indivíduos que se enquadravam nos critérios de inclusão (praticantes de escalada de ambos os sexos e praticantes a mais de um ano, que assinarem o termo de consentimento). E excluídos da pesquisa os praticantes de escalada que tinham menos de um ano da prática da escalada e não assinaram o termo de consentimento.

Os dados foram analisados de forma quantitativa e qualitativa através de análise de conteúdo proposta por Laurence Bardin e estatística percentual. O estudo desses dados segue os pressupostos que: "A intenção da análise de conteúdo é a inferência de conhecimentos relativos às condições de produção (ou, eventualmente, de recepção), inferência esta que recorre a indicadores (quantitativos ou não)" (BARDIN, 2011, p. 34). A análise de conteúdo foi organizada em quatro categorias sendo a primeira sobre a relação da escalada com a construção de valores, a segunda sobre as mudanças que ocorreram após a prática da escalada, a terceira sobre as ações sustentáveis realizadas na sua prática e a quarta sobre a conservação do local em que pratica a escalada. E estatisticamente a análise foi apresentada por meio de gráficos com percentual.

O instrumento de coleta de dados utilizado foi um questionário online da plataforma Google Forms. Cada vez mais o uso da internet vem se destacando como potencial ferramenta que facilita o acesso a informações e a disseminação de 
conhecimento. Assim, a busca por novas tecnologias para facilitar e auxiliar o desenvolvimento nas pesquisas científicas é uma realidade que está cada vez mais presente (FALEIROS, 2016).

O questionário foi validado por professores e membros do grupo de estudo LEPAFS (Laboratório de Estudos e Pesquisas em Atividade Física e Saúde) da Universidade Federal da Paraíba. O mesmo continha questões abertas e fechadas sobre os valores adquiridos com a prática da escalada.

Esta pesquisa integra um projeto de pesquisa longitudinal (2018-2022) intitulado “ESPORTES DE AVENTURA E NA NATUREZA: DESENVOLVIMENTO, PEDAGÓGICO, SOCIAL E CULTURAL" com o CAAE: 95386418.4.0000.8069 aprovado pelo Comitê de Ética do Centro de Ciências da Saúde da Universidade Federal da Paraíba, através do Parecer $n^{\circ} 2.856 .558$ e tem como objetivo geral de verificar o potencial dos esportes e atividades físicas a natureza e de aventura para os desenvolvimentos pedagógicos, sociais e culturais na área da Educação Física.

O presente estudo respeitou os aspectos éticos preconizados pela Resolução CNS 466/12, no art. III, que implica no respeito ao participante da pesquisa em sua dignidade e autonomia, reconhecendo sua vulnerabilidade, assegurando sua vontade de contribuir e permanecer, ou não, na pesquisa, por intermédio do Termo de Consentimento Livre e Esclarecido (BRASIL, 2012).

\section{Resultados}

Com base na literatura sobre o tema, Bertuzzi e colaboradores (2011) afirmam que a prática de escalada exige por parte dos seus praticantes algumas habilidades como resistência física, concentração e força, e que para praticar esta atividade estes indivíduos precisam ter materiais que garantam sua segurança durante a escalada bem como o 
conhecimento da área na qual pretende escalar. Bahia e Sampaio (2007) ressaltam que as pessoas têm procurado praticar atividades físicas ao ar livre para aliviar a tensão e o estresse do dia a dia.

É visto que tal prática vem desenvolvendo em seus praticantes uma série de benefícios, incluindo o contato com a natureza, a conscientização ambiental, melhor desempenho na vida profissional e social entre outros que estão interligados a prática da escalada. Nos dados coletados pudemos relacionar o que foi obtido na literatura atual com as informações coletadas pelos praticantes de escalada sobre a construção de valores que estes adquiriram na prática da escalada esportiva. Nesse sentido os Gráficos 1, 2, 3, 4 e 5 dispostos abaixo representam o perfil dos praticantes envolvidos na pesquisa e o tempo que praticam a escalada.

\section{Gráfico 1: Sexo dos participantes}

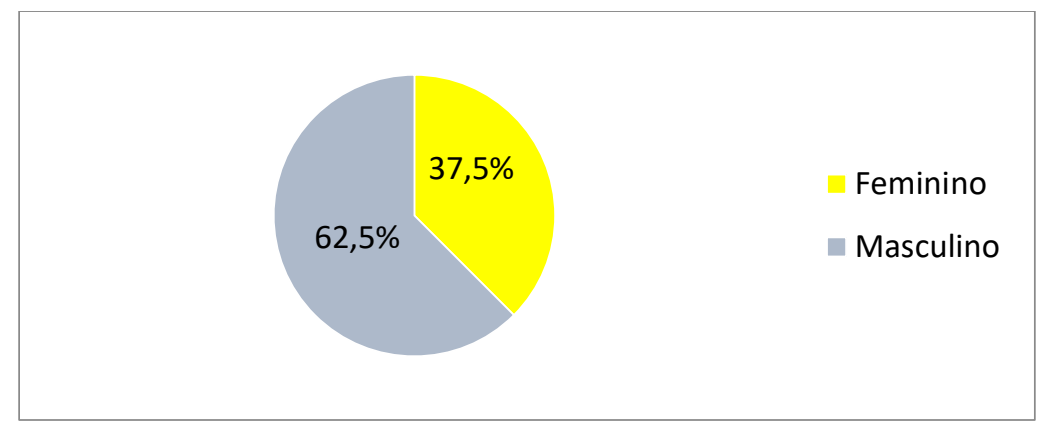

Fonte: Dados da pesquisa, 2019.

No Gráfico 1, observa-se que a maioria dos praticantes de escalada da pesquisa são do sexo masculino apresentando um total de $62,5 \%$ e $37,5 \%$ do sexo feminino.

\section{Gráfico 2: Faixa etária}




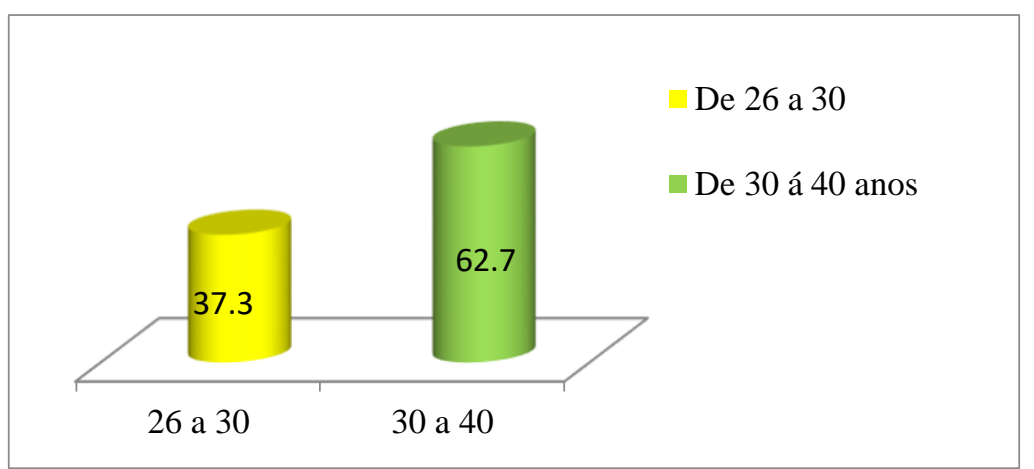

Fonte: Dados da pesquisa, 2019.

No Gráfico 2, observa-se que a maioria dos praticantes da pesquisa estão na faixa etária entre 30 a 40 anos com 62,7\% e a minoria está entre a faixa etária de 26 a 30 anos com 37,3\%. Percebe-se que não houve indivíduos com idade de 20 a 25 anos, como descrita nos critérios metodológicos.

\section{Gráfico 3: Profissão}

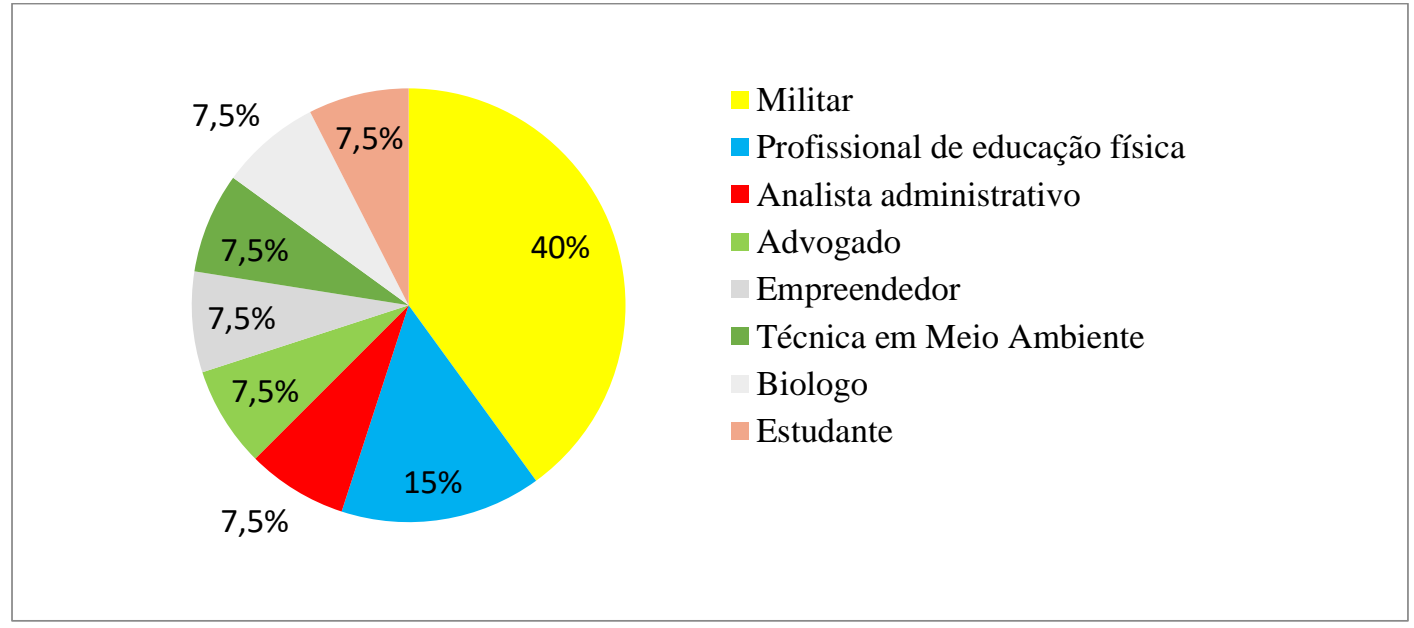

Fonte: Dados da pesquisa, 2019.

Observa-se no Gráfico 3 que $40 \%$ dos praticantes de escalada da pesquisa são militares, $15 \%$ são profissionais de educação física e que os demais são: advogados com 7,5\%, biólogos com 7,5\%, empreendedor com 7,5\%, estudante com 7,5\%, técnico em ambiente com 7,5\% e analista administrativo também com 7,5\%.

\section{Gráfico 4: Grau de escolaridade}




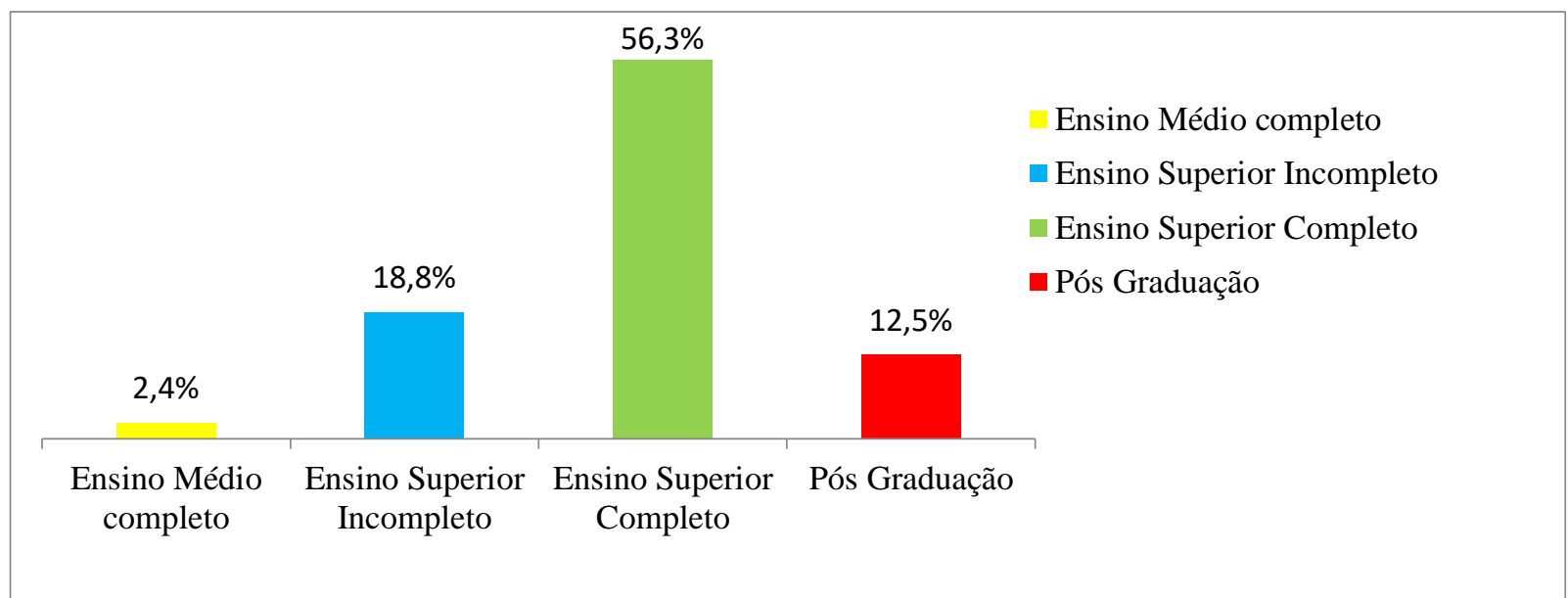

Fonte: Dados da pesquisa, 2019.

O Gráfico 4 indica que 56,3\% dos participantes da pesquisa possuem o ensino superior completo, seguido de $18,8 \%$ com ensino superior incompleto, $12,5 \%$ possuem pós - graduação e apenas 2,4\% possuem apenas o ensino médio o que denota que a grande maioria possui curso superior ou seu curso está em andamento.

Gráfico 5: Período que pratica a escalada

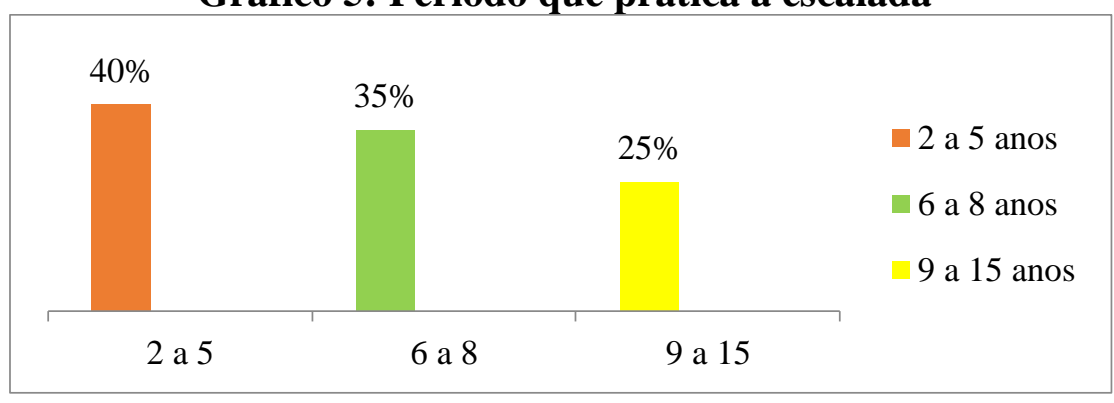

Fonte: Dados da pesquisa, 2019.

No Gráfico 5 é possível observar que $40 \%$ dos praticantes de escalada deste estudo realizam esta atividade de 2 (dois) a 5 (cinco) anos, $35 \%$ de 6 (seis) a 8 (oito) anos e $25 \%$ de 9 (nove) a 15 (quinze) anos. Além dos dados expostos no gráfico foi questionado em qual lugar estes indivíduos costumam praticar a escalada e estes afirmaram que praticam a escalada em diferentes municípios paraibanos entre eles Patos, Pilões, Araruna, João Pessoa entre outros.

Pereira e Piccolo (2010) afirmam que no decorrer da prática da escalada os indivíduos experimentam uma gama de emoções, sensações e sentimentos e aprendem a superar obstáculos e a conhecer seus limites. Sendo assim, os Gráficos 6 e 7 destacam 
alguns valores citados pelos indivíduos da pesquisa sobre os valores e benefícios adquiridos através da prática da escalada.

\section{Gráfico 6: Valores desenvolvidos na prática da escalada}

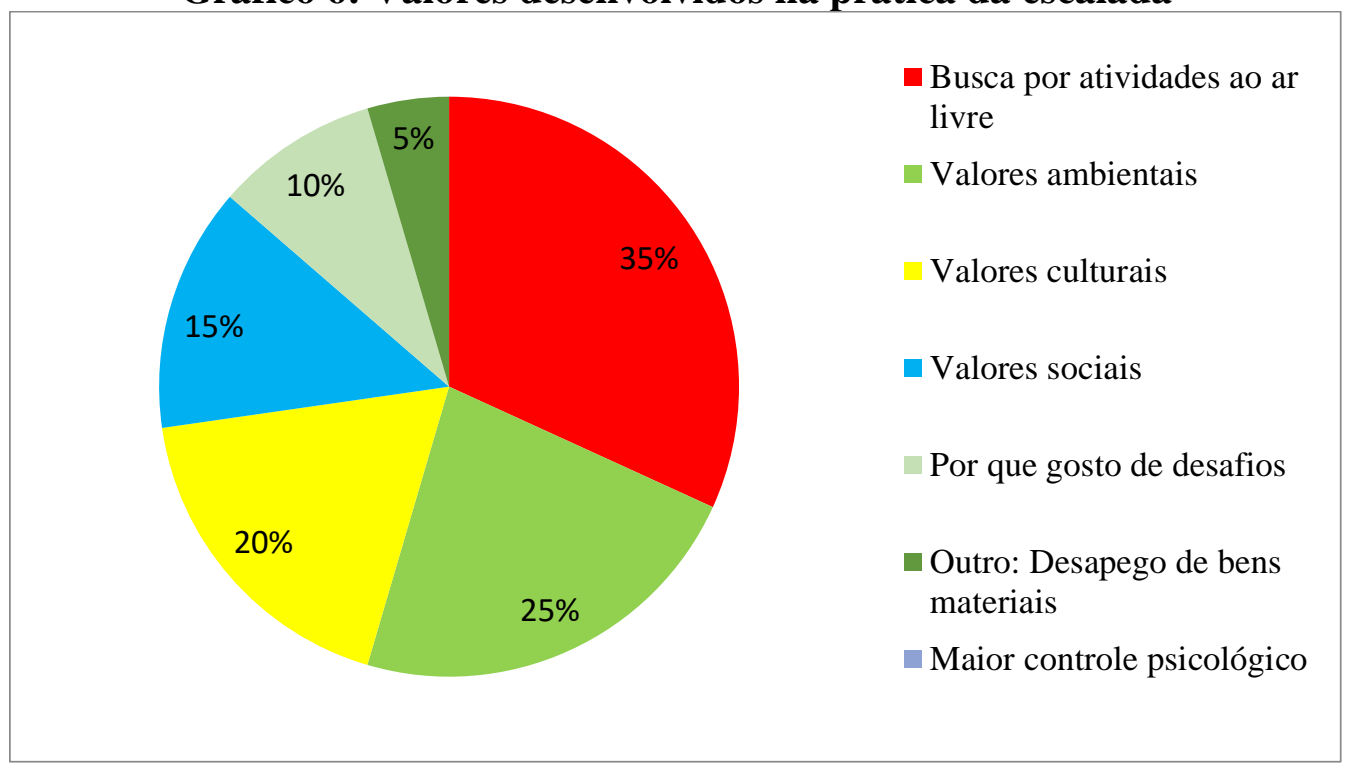

Fonte: Dados da pesquisa, 2019.

Observa-se no Gráfico 6 que 35\% dos praticantes citaram a busca por atividades ao ar livre como um dos valores adquiridos, $25 \%$ afirmaram que passaram a valorizar a cultura, $15 \%$ os valores sociais, $10 \%$ desenvolveram o gosto por desafios e $5 \%$ afirmaram que passaram a valorizar menos os bens materiais e nenhum dos praticantes marcaram o controle psicológico como um dos valores adquiridos por eles durante a prática da escalada.

Diante do exposto no gráfico acima, se verifica que durante a prática da escalada os indivíduos passaram a adquirir valores positivos como confiança, equilíbrio, motivação, gosto por desafios, valores sociais e culturais, através da socialização com outros praticantes, menor preocupação com bens materiais e maior contato com a natureza através da atividade ao ar livre.

Araújo; Oliveira Júnior e Azevedo (2015) apontam que a os indivíduos que praticam atividades na natureza como a escalada, acabam desenvolvendo valores ambientais. Conforme os autores, na medida em que o homem passa a ter mais contato 
com a natureza ele passa a ter uma maior consciência ambiental e passa a desenvolver sentimentos de preservação e cuidado.

Silva (2006) destaca que o habitussócio-ambiental contemporâneo tem como característica a organização e o desenvolvimento social através dos nossos posicionamentos políticos em relação ao meio ambiente. Nesta direção, a construção de uma cultura de preservação depende não apenas dos fatores sociais, políticos e econômicos, mas da forma que entendemos a preservação ambiental e tudo que ela representa de positivo para nossas vidas. Desta forma, a prática de esportes e atividades na natureza representa o despertar da nossa consciência ambiental já que temos a oportunidade de estarmos mais próximos do meio ambiente repensando sua importância e as consequências de nossas atitudes em relação a ele.

Nesse contexto, Silva (2006) destaca que:

[...] "habitussócio-ambiental" é uma disposição de padrões comportamentais, perceptivos, representacionais e simbólicos que estão ancorados numa dimensão prática e interativa das relações e ações sociais, com uma perspectiva natural (ambiental) e humana (sócio-individual) dentro do sistema de desenvolvimento global do mundo contemporâneo (SILVA, 2006, p. 229).

Diante deste entendimento a ação individual, no que diz respeito à preservação, reflete diretamente no coletivo pois quando cada um faz a sua parte todos conseguem garantir mais qualidade de vida.

Nesta direção Comunello (2014) destaca que a ideia de "desenvolvimento sustentável", surgiu a partir da necessidade de propor uma integração entre o desenvolvimentismo e as questões ambientais e sociais. Diante disso todas as ações em prol do meio ambiente surgiram no Brasil através das conferências, pactos, debates, acordos e agendas. Na prática de esportes na natureza as questões ambientais também foram ganhando força sendo cada vez mais comuns os praticantes destas modalidades desenvolvam a preocupação com as questões ambientais.

A prática de esportes na natureza proporciona nos indivíduos sensações de bem 
estar, melhora da qualidade de vida, conscientização sobre as questões do meio ambiente, fuga do estresse do cotidiano, maior capacidade de enfrentar o desafio e o risco, melhora para lidar com as emoções e sensações o aumento do bem-estar, prazer, da autoestima, socialização, motivação em geral, condicionamento físico e força muscular (TAHARA; CARNICELLI, FILHO, 2009).

Considerando o que os autores supracitados relatam a escalada por ser ao ar livre desperta nos indivíduos diferentes sensações de bem estar e valores necessários para vida em sociedade, contribuindo de forma significativa para a valorização e preservação do meio ambiente.

\section{Gráfico 7: Benefícios que a escalada proporciona}

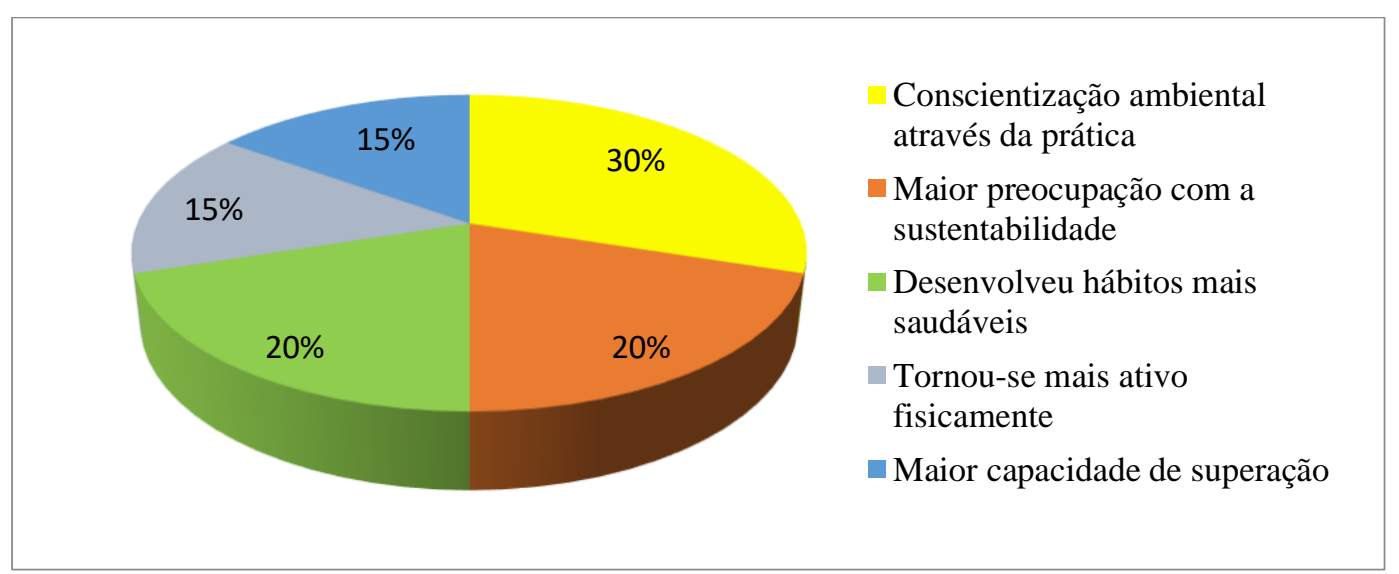

Fonte: Dados da pesquisa, 2019.

Observa-se no Gráfico 7 que 30\% dos praticantes de escalada do estudo passaram a serem mais conscientes sobre as questões ligadas ao meio ambiente e sua preservação, $20 \%$ alegaram ter desenvolvido uma maior preocupação com a sustentabilidade, $20 \%$ desenvolveram hábitos mais saudáveis, $15 \%$ tornaram-se mais ativos fisicamente e $15 \%$ passaram a se sentirem mais seguros e capazes de superar desafios.

É notável a partir do Gráfico 7 que a prática da escalada despertou nos praticantes por meio do contato com a natureza a conscientização sobre a preservação ambiental, sustentabilidade, autoestima e superação dos desafios, desenvolvimento de hábitos saudáveis e maior atividade física. 
Diante disso, Bahia e Sampaio (2007) destacam que a necessidade de vivenciar atividades e momentos de lazer na natureza pelo homem representa a busca por uma reaproximação do meio natural levando a sociedade a se reengajar nas causas ambientais e na conscientização sobre a importância do meio ambiente para a humanidade. Neste sentido, praticar a escalada desperta a vontade de se reaproximar do meio natural e de preservá-lo para as futuras gerações. Quanto mais o homem se aproxima da natureza mais ele entende que é preciso cuidar e preservar para que este contato não seja perdido. Porém é sempre fundamental destacar que na educação para o lazer de aventura é necessário observar regras e condutas, para que as práticas de escalada não se aproximem de características de turismo de aventura, que muitas vezes não se preocupam em uma construção sólida de valores ambientais nos seus praticantes.

\section{Gráfico 8: Atitudes de preservação que realizam durante a prática da escalada.}

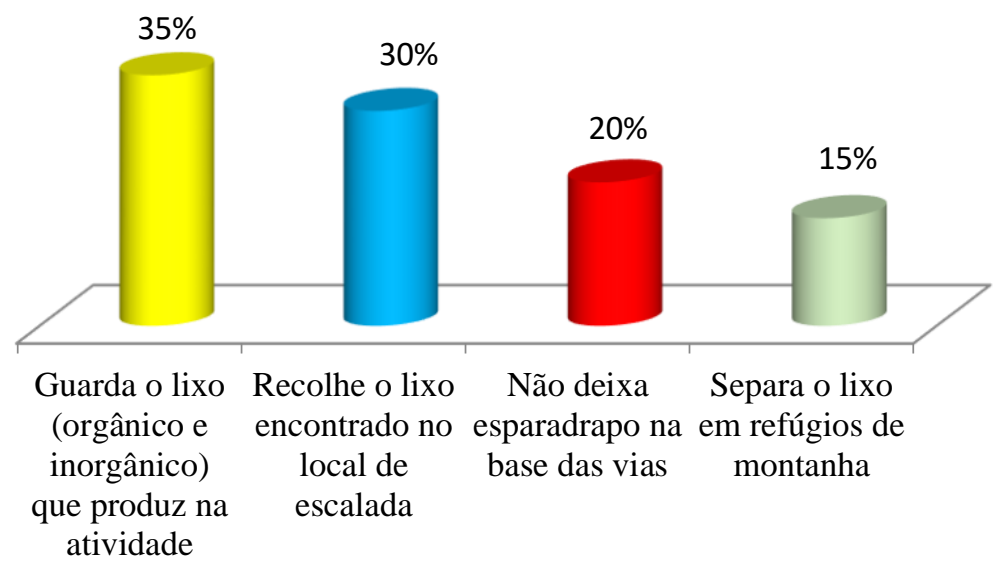

Fonte: Dados da pesquisa, 2019.

O Gráfico 8 representa algumas das atitudes de preservação que os escaladores realizam durante a prática da escalada, e é possível observar que 35\% afirmaram guardar o lixo orgânico e não orgânico que produzem durante a atividade, 30\% que recolhem o lixo encontrado no local da escalada, $20 \%$ afirmam que não deixam esparadrapos na base 
das vias e $15 \%$ afirmam que separam o lixo em refúgios da montanha. Silva (2006) aborda que habitussócio-ambiental é uma disposição do desenvolvimento de diversos padrões comportamentais que estão ancorados através da dimensão prática. Neste sentido, podemos observar que a prática da escalada desenvolve em seus praticantes uma conscientização no cuidado com o descarte do lixo que pode ser levada para todos os seus contextos familiares, sociais e laborais, auxiliando em uma disseminação dos preceitos de cuidados com o meio ambiente.

Bahia e Sampaio (2007) mostram que as atividades realizadas na natureza inspiram ações de preservação dos recursos naturais e culturais onde estas atividades são realizadas. Visando preservar estes momentos em contato com o meio ambiente, os praticantes de escalada acabam desenvolvendo ações organizadas de preservação seja por meio do recolhimento do lixo, da não poluição das bases das vias com esparadrapos, e da separação e recolhimento do lixo orgânico e inorgânico produzido durante a escalada. Essa conscientização pode ser perpassada também para diversos contextos educacionais, pois é relevante destacar que a prática da escalada gerou efeitos positivos em adultos que participaram desta pesquisa, podendo assim ser o indício de sucesso para o desenvolvimento de ações e projetos envolvendo escolas e universidades, ampliando a conscientização desde cedo em crianças, adolescentes e jovens para que se possa ter um melhor tratamento do descarte de resíduos, reduzindo os altos índices de poluição e contaminação de diversos lugares naturais.

Perante as perguntas abertas realizadas na coleta de dados, foram categorizados os resultados, sendo a primeira sobre a relação da escalada com a construção de valores, a segunda sobre as mudanças que ocorreram após a prática da escalada, a terceira sobre as ações sustentáveis realizadas na sua prática e a quarta sobre a conservação do local em que pratica a escalada. 
Tabela 1: Tema 1 - A relação da escalada com a construção de valores ambientais.

\begin{tabular}{|c|c|c|c|}
\hline Categoria & Subcategoria & Unidade de Registo & Unidade de Contexto \\
\hline $\begin{array}{l}\text { 1- A relação da } \\
\text { escalada com a } \\
\text { construção de valores } \\
\text { ambientais }\end{array}$ & $\begin{array}{l}\text { Preservação do meio } \\
\text { ambiente }\end{array}$ & $\begin{array}{l}\text { Respeito ao meio } \\
\text { ambiente }\end{array}$ & $\begin{array}{l}\text { Preservar o meio ambiente. } \\
\text { Acabamos aprendendo por } \\
\text { conviver com outros escaladores } \\
\text { que defendem certos valores e } \\
\text { ideias, e por perceber como a } \\
\text { escalada é um esporte que integra } \\
\text { a natureza o homem. } \\
\text { Maior atenção à natureza. } \\
\text { Aprender a preservar o meio } \\
\text { ambiente, pois precisamos dele. } \\
\text { A escalada gera uma relação de } \\
\text { confiança muito grande entre os } \\
\text { participantes, além de encontrar } \\
\text { entre os seus princípios (da } \\
\text { escalada) o pleno respeito ao } \\
\text { meio ambiente. } \\
\text { Preservação, olhamos de forma } \\
\text { diferente, pensar que meus olhos } \\
\text { talvez não vejam essas paisagens } \\
\text { no futuro. } \\
\text { Sinto que faço parte do meio } \\
\text { ambiente e que tenho que cuidar } \\
\text { para que a área permaneça assim } \\
\text { para as futuras gerações. } \\
\text { Cuidado com local que pratica. } \\
\text { Consciência ecológica. } \\
\text { Através do esporte aprendi a dar } \\
\text { mais valor ao meio ambiente e } \\
\text { sabero seu real valor. }\end{array}$ \\
\hline
\end{tabular}




\begin{tabular}{|l|l|l}
\hline Mudança no estilo de vida & $\begin{array}{l}\text { Maior capacidade de } \\
\text { vencer desafios } \\
\text { Maior interação social }\end{array}$ & $\begin{array}{l}\text { Interação com amigos, saúde } \\
\text { mental. } \\
\text { Parceria. } \\
\text { Desenvolvimento da capacidade } \\
\text { de vencer desafios. } \\
\text { Estilo de vida. } \\
\text { A percepção da vida através da } \\
\text { escalada que vai além de uma } \\
\text { simples prática, é a amizade } \\
\text { adquirida à sabedoria de dar um } \\
\text { passo de cada vez e o } \\
\text { dissentimento de agir na hora } \\
\text { certa, da forma certa. }\end{array}$ \\
\hline
\end{tabular}

Fonte: Dados da pesquisa, 2019.

Observa-se na categoria 1 que os praticantes de escalada desenvolveram ao longo do tempo a conscientização sobre a preservação do meio ambiente, maior interação social e capacidade de vencer os desafios. Tais valores são frutos da convivência entre os praticantes, do contato com a natureza e dos obstáculos superados durante a prática desta atividade. Como apontado Vargas; Silva e Amaral (2015) somente a prática da escalada por si só não permitirá a construção de valores ambientais. O momento facilitador de um espaço mais lúdico e de lazer, em especial com a construção de valores ambientais, faz com que a interação social seja um ponto positivo para a troca de informações e experiências, formado uma grande teia de compartilhamentos de práticas bem sucedidas. De acordo com Gomes (2014) a compreensão do que geralmente é designado como lazer enraíza-se na ludicidade e constitui uma prática social complexa que abarca uma multiplicidade de vivências culturais situadas em cada contexto. É relevante destacar que muitas destas vivências devem ser valorizadas em prol do desenvolvimento de ações que permitam justamente uma integração dos benefícios dos momentos de lazer, até mesmo como um espaço para novas aprendizagens. Neste sentido, a escalada pode abarcar diversas contribuições pelo formato mais espontâneo de prazer pela prática, sendo o 
entretenimento e a ludicidade fatores favoráveis para a adoção de um estilo de vida mais sustentável e de respeito aos valores ambientais.

Prado (2016) destaca que além dos valores ambientais, a escalada desperta em seus praticantes a capacidade de socialização com outros indivíduos, despertando neles a cooperação social. Quando se socializa, o homem amplia suas relações e consegue a partir do contato com o outro conhecer a própria identidade.

Tabela 2: Tema 2 - As mudanças no tempo destinado ao lazer com a prática da escalada.

\begin{tabular}{|c|c|c|c|}
\hline Categoria & Subcategoria & $\begin{array}{l}\text { Unidade de } \\
\text { Registo }\end{array}$ & Unidade de Contexto \\
\hline $\begin{array}{l}\text { 2- As mudanças ocorridas } \\
\text { após a prática da escalada }\end{array}$ & $\begin{array}{l}\text { Melhora da saúde física, } \\
\text { psicológica e cognitiva. }\end{array}$ & $\begin{array}{l}\text { Melhor disposição } \\
\text { física. } \\
\text { Maior concentração. } \\
\text { Maior equilíbrio } \\
\text { emocional. } \\
\text { Superação das } \\
\text { dificuldades. } \\
\text { Cuidados com a } \\
\text { saúde e a } \\
\text { alimentação. }\end{array}$ & $\begin{array}{l}\text { Me tornei mais ativo fisicamente. } \\
\text { Melhor disposição física. } \\
\text { Manter um bom condicionamento } \\
\text { físico. } \\
\text { Concentração e disposição. } \\
\text { Mudanças de humor, mais } \\
\text { disposição fisica e a busca por } \\
\text { novos desafios. } \\
\text { Mais paciência, melhor humor } \\
\text { Preocupação com a saúde. } \\
\text { A alimentação foi gradativamente } \\
\text { mudando. } \\
\text { Passei a escutar mais meu corpo. }\end{array}$ \\
\hline & $\begin{array}{l}\text { Conscientização } \\
\text { ambiental }\end{array}$ & $\begin{array}{l}\text { Maior contato com } \\
\text { a natureza e } \\
\text { preocupação com o } \\
\text { meio ambiente }\end{array}$ & $\begin{array}{l}\text { Prático esporadicamente, mas } \\
\text { percebi que busco cada vez mais } \\
\text { atividades ao ar livre, e busco } \\
\text { alternativas menos impactantes } \\
\text { para o meio ambiente no meu dia- } \\
\text { a-dia. } \\
\text { Consciência ambiental, } \\
\text { confiança, senso de } \\
\text { responsabilidade. } \\
\text { Ter mais contato com a natureza. } \\
\text { A Interação cultural aprendendo e } \\
\text { socializando com as pessoas que } \\
\text { ali estão presentes. }\end{array}$ \\
\hline
\end{tabular}




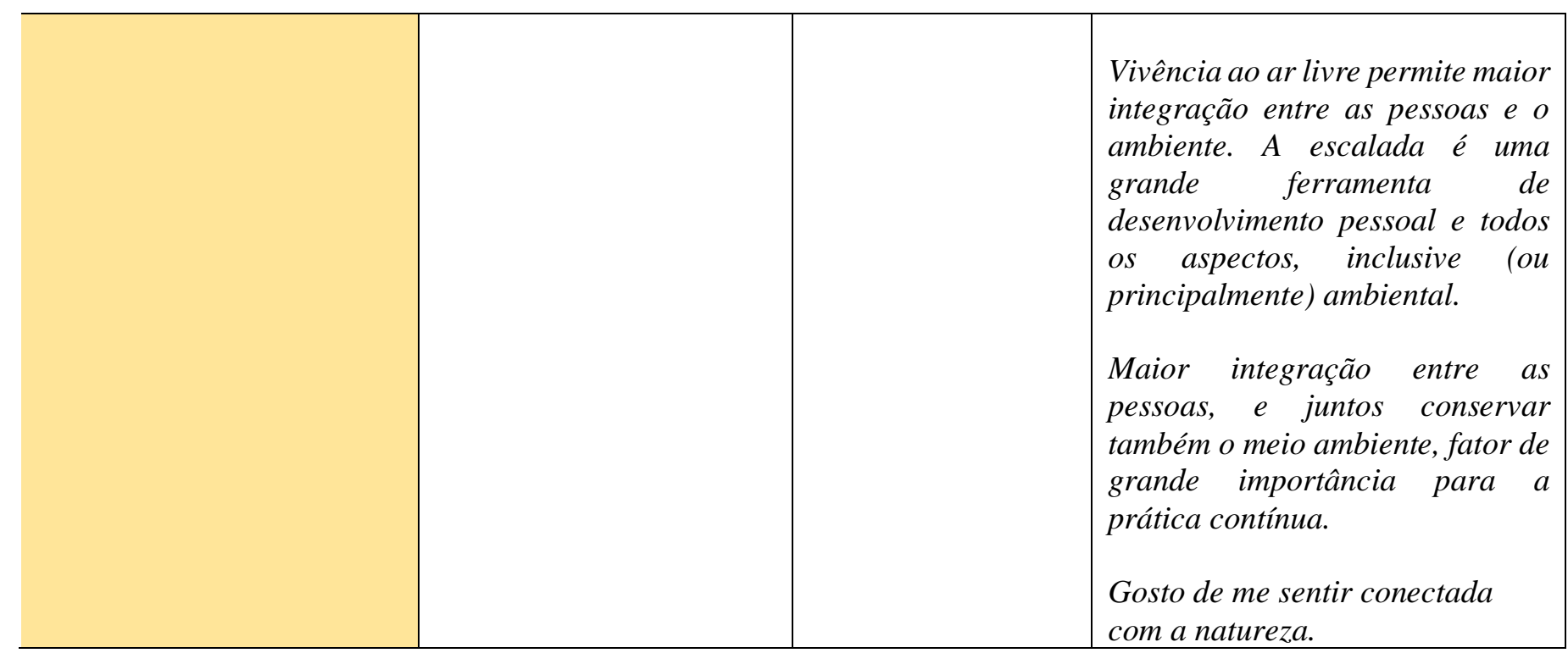

Fonte: Dados da pesquisa, 2019.

Observa-se na categoria 2 que as mudanças no tempo destinado ao lazer citadas pelos praticantes de escalada, tiveram grande destaque no respeito à natureza e a sua preservação, além da melhora da saúde física, psicológica e cognitiva. Os mesmos afirmaram que com a prática da escalada no tempo de lazer, passaram a se preocupar mais com o meio ambiente e a saúde física, buscando ter uma vida mais saudável. Também afirmaram que passaram a se sentir mais seguros, equilibrados e capazes de enfrentar os desafios da vida. Dentro desta perspectiva, o habitus ambiental desenvolvido pela prática, oferece uma ampliação da percepção dos praticantes e do mundo que os cerca. Esta reflexão gera no participante uma maior observação na gestão de seu tempo, proporcionando assim mais dedicação ao lazer através da prática da escalada, sendo essa uma grande promotora de diversos benefícios.

Por fim definiram que com a prática da escalada tiveram mudanças no corpo, na mente, na concentração e no equilíbrio, desenvolvendo habilidades necessárias para terem uma maior qualidade de vida.

Tahara e CarnicelliFilho (2009) afirmam que a prática das atividades físicas de aventura na natureza além de melhorar a qualidade de vida dos praticantes também desperta neles uma maior preocupação com o meio ambiente e maior capacidade de lidar 
com os problemas do cotidiano e com as dificuldades da vida. Conforme Gomes (2014) devido às características que tradicionalmente são atribuídas aos lazer, tais como liberdade e prazer, o lazer por estar circunscrito ao chamado "tempo livre", passa a ser assimilado como contraponto do trabalho e assim pode desenvolver diversas outras habilidades sociais e até mesmo individuais, como o equilíbrio emocional e concentração. Estas habilidades se tornam importantes atualmente, em especial pela grande demanda física e psicológica que muitas atividades laborais podem exigir. E tais mudanças no estilo de vida dos praticantes também podem refletir positivamente nos seus ambientes de trabalho e no convívio social entre os pares.

Tabela 3: Tema 3 - Ações sustentáveis realizadas na prática da escalada.

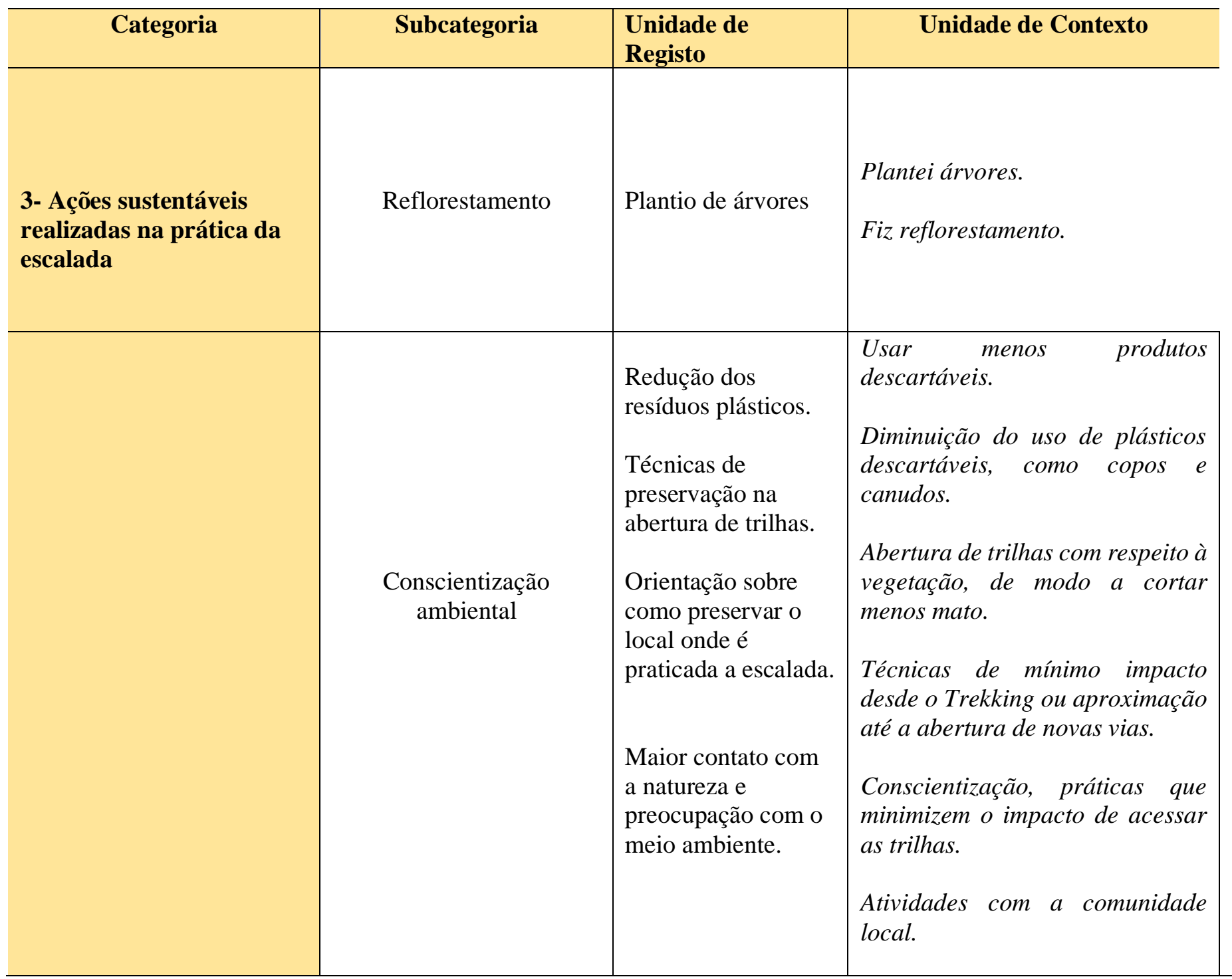




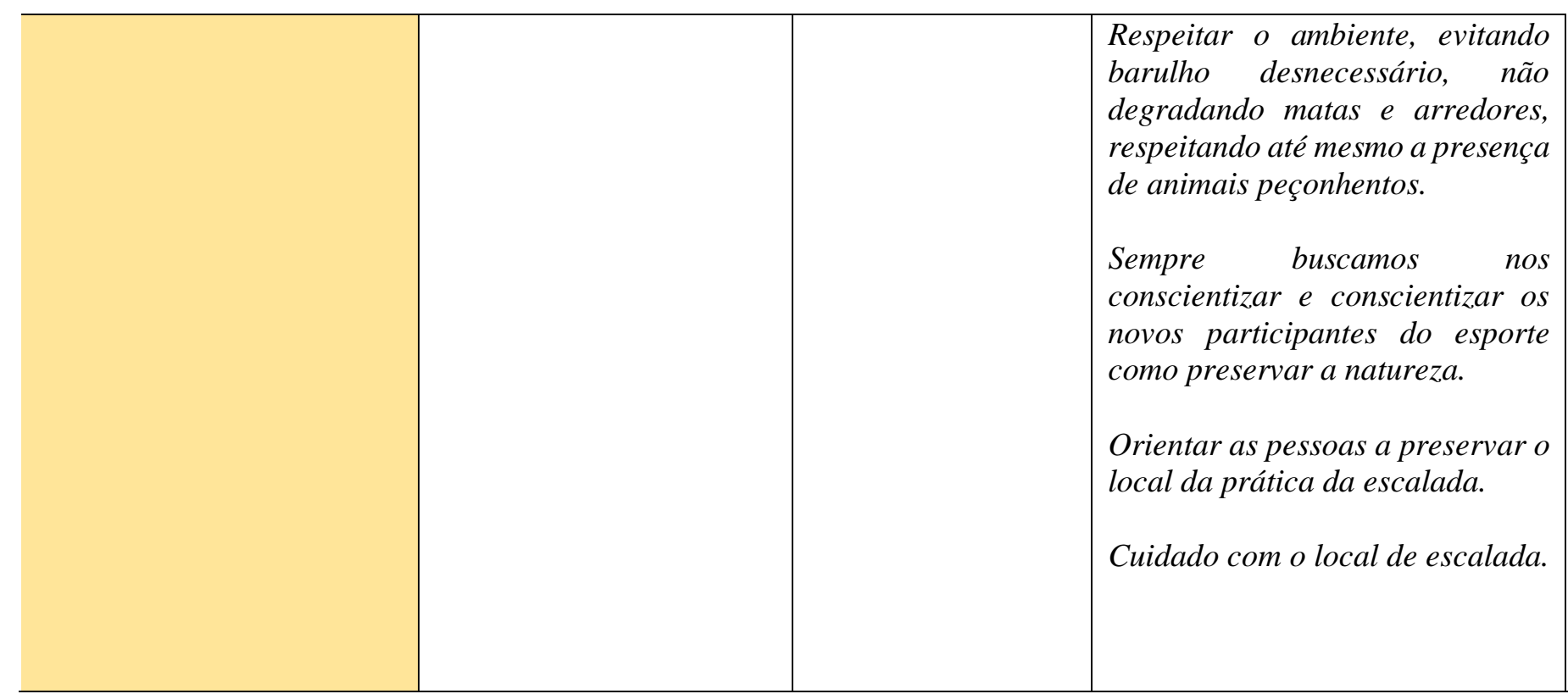

Fonte: Dados da pesquisa, 2019.

Na categoria 3 sobre as ações sustentáveis realizadas na prática da escalada, observou-se que os praticantes tem realizado ações sustentáveis como a redução dos resíduos plásticos, o reflorestamento, a conscientização ambiental, o uso de técnicas de preservação na abertura de trilhas e orientação a comunidade local e orientação aos visitantes que vem praticar a escalada para preservação do lugar. Tais ações demonstraram de forma evidente que a prática da escalada acaba gerando em seus praticantes a necessidade de cuidar do meio ambiente por meio destas ações sustentáveis. Mesmo não envolvendo a prática da escalada em rochas diretamente, a realização das trilhas se torna outra atividade conjunta e é possível perceber uma grande preocupação entre os participantes deste estudo na preservação e manutenção do acesso aos locais da realização da escalada. Atividades como acampamentos e contemplação da natureza também completam os momentos de lazer e podem estar diretamente associados à ludicidade, em especial na fala "atividades com a comunidade local" ou até no "plantio de árvores". Tais atividades de interação social e com a natureza revelam ao praticante um campo de conexão com os preceitos do lazer e lúdico, trazendo momentos de prazer, criatividade e cooperação. De acordo com Lopes (2014), a ludicidade, enquanto 
fenômeno e condição de ser do humano, está presente em cada pessoa e em todas as culturas, manifestando-se de diversas formas e, na multiplicidade dos seus efeitos ela é potencializadora da intercompreensão e da comunicação humana. A Ludicidade está intrinsecamente relacionada à ação (transmissão), da interação (partilha) e na transação comunicativa (compartilha simbólica), sendo estas dimensões inclusivas do processo da comunicação. Nesse sentido, a lógica do sistema social resulta dos processos ativamente construídos e negociados: compreendidos e aceitos, compreendidos e rejeitados, ignorados e abandonados (LOPES, 2014). O que consolida com as falas dos participantes através das transmissões de conhecimento com as ações (mais experientes, guias e instrutores para os novatos e iniciantes nas práticas), com a partilha de experiências vividas no contexto da escalada e na transação comunicativa com a comunidade local, levando uma maior abrangência sobre o entendimento de preservação para todos.

Betiollo e Santos (2003) apontam que a prática das atividades na natureza quando feita com amor, sentimento e respeito à natureza e aos demais, leva os praticantes a desenvolverem a consciência ambiental e a refletir sobre as atitudes que podem prejudicar o equilíbrio do meio ambiente. Na medida em que se mantém o contato com a natureza, se desenvolve o amor por ela e o respeito por tudo que ela tem a nos oferecer.

Tabela 4: Tema 4 - Conservação do local em que pratica a escalada.

\begin{tabular}{|c|c|c|c|}
\hline Categoria & Subcategoria & $\begin{array}{l}\text { Unidade de } \\
\text { Registo }\end{array}$ & Unidade de Contexto \\
\hline & $\begin{array}{l}\text { Conscientização dos } \\
\text { praticantes sobre a } \\
\text { importância da } \\
\text { preservação local }\end{array}$ & Preservação & $\begin{array}{l}\text { Sim, conversando com visitantes. } \\
\text { Sim. Sempre tomo cuidado de } \\
\text { preservar e alertar aos demais } \\
\text { frequentadores, por exemplo, da } \\
\text { presença de ninhos próximos a } \\
\text { vias de escalada para garantir } \\
\text { que os pássaros não sejam } \\
\text { incomodados pela nossa ação. } \\
\text { Limpando e orientando pessoas à } \\
\text { conservação do meio ambiente. }\end{array}$ \\
\hline
\end{tabular}




\begin{tabular}{|c|c|c|c|}
\hline & & & $\begin{array}{l}\text { Tentando impactar o mínimo } \\
\text { possível no ambiente e orientando } \\
\text { as pessoas como proceder nesse } \\
\text { local. } \\
\text { Sim, aplicando a metodologia de } \\
\text { mínimo impacto orientada pelas } \\
\text { normas vigentes e incentivando a } \\
\text { todos a fazerem o mesmo. } \\
\text { Preservando e orientando. }\end{array}$ \\
\hline $\begin{array}{l}\text { 4- Conservação do local } \\
\text { em que pratica a escalada }\end{array}$ & $\begin{array}{c}\text { Evitando a poluição do } \\
\text { local }\end{array}$ & $\begin{array}{l}\text { Cuidando do local } \\
\text { onde a escalada é } \\
\text { praticada }\end{array}$ & $\begin{array}{l}\text { Evitando sujar o local da prática } \\
\text { da escalada. } \\
\text { Sim, buscando respeitar as regras } \\
\text { que por ventura o local tem, e } \\
\text { contribuindo com sua } \\
\text { preservação evitando deixar lixo } \\
\text { ou qualquer outra marca nos } \\
\text { locais de escalada. } \\
\text { Sim, limpando a área. } \\
\text { Não deixando lixo nos locais que } \\
\text { escalamos. } \\
\text { Não poluindo o local e tendo } \\
\text { cuidado sempre com o meio } \\
\text { ambiente. } \\
\text { Mantendo o ambiente da maneira } \\
\text { que encontramos }\end{array}$ \\
\hline
\end{tabular}

Fonte: Dados da pesquisa, 2019.

Sobre a conservação do local de prática da escalada, a categoria 4 demonstra com clareza que os praticantes de escalada demonstraram preocupação com a conservação do lugar, realizando estratégias ecológicas para manter o ambiente natural preservado. Entre as ações os participantes do estudo afirmaram que evitam poluir o lugar recolhendo seus resíduos, procuram realizar a prática da escalada sem causar danos ao meio ambiente e incentivando e orientando os praticantes e a comunidade local a preservar o ambiente. Porém, é importante ressaltar aqui neste estudo que o grande fluxo de praticantes, mesmo tomando as devidas precauções e cuidados com a natureza, pode ocasionar desequilíbrio ambiental. Esta é uma ação fundamental que os próprios praticantes devem estabelecer 
com a comunidade local, pois não é somente o ambiente natural das rochas que compõe o espaço de interação, mas sim as trilhas, áreas de uso comum (acampamento, banheiros etc.) e também a zona rural (hortas, regiões agrícolas) e o empenho e conscientização devem servir como uma engrenagem para fomentar a área da prática de maneira sustentável economicamente para os habitantes locais e que os praticantes da escalada interajam com o local não somente como um "Day Use", mas que observe como este espaço na natureza está se preservando continuamente. Entretanto, uma grande impossibilidade para o desenvolvimento sustentável de determinadas regiões de prática de escaladas, pode ser identificada como a dificuldade em desenvolvimento de parcerias nos locais de prática (acesso, interesses econômicos e governamentais) o que infelizmente pode causar grandes limitações tanto para a preservação da natureza como para a prática sustentável da região.

Costa (2000) faz menção à relação afetiva que o praticante tem com a natureza e afirma que este vínculo com o meio ambiente desperta a conscientização sobre os problemas ambientais e consequentemente a mudança de atitudes e comportamentos em relação à preservação ambiental.

Diante do exposto pela autora, os praticantes de esportes na natureza passam a desenvolver hábitos de preservação ambiental e, neste sentido, observa-se que durante a prática da escalada os praticantes passam a compreender a importância de desenvolver atitudes de preservação em relação a estes lugares.

Conforme Silva (2006) o habitussócio-ambiental é uma disposição de padrões comportamentais que estão relacionados na prática e interação das relações, promovido pela conscientização coletiva em prol da preservação da natureza. De acordo com a autora, conceito de "natural" é uma construção social ao mesmo tempo em que o "social" encontra no natural e no simbólico os próprios elementos de sua efetivação 
conceitual.

\section{Considerações Finais}

No decorrer da pesquisa foi possível observar que poucos estudos abordam este tema, no entanto, podemos constatar que os praticantes de escalada passaram a se preocupar mais com as questões ambientais e a mudar suas relações e atitudes diante da vida. Além de adquirirem força, equilíbrio, coordenação motora, aumento da concentração, saúde física, mental, psicológica, afetiva e social também sentiram a necessidade de divulgar os valores ambientais entre os pares. O que demonstra que a prática da escalada contribui de forma positiva para a construção de valores, principalmente ambientais.

É relevante destacar que através da experiência da escalada como lazer, que carrega junto momentos de prazer, descontração, ludicidade e prazer, existe o desenvolvimento de uma significativa conscientização ao habitus ambiental. Sem existir formalidade e obrigatoriedade na execução de tarefas e trabalho, os participantes comprovam que no seu momento de interação do tempo livre com a escalada, apresentam novas possibilidades de aprendizagem que acabam carregando para o seu cotidiano diário e estimulando até mesmo outras pessoas de seu círculo familiar e social. Entretanto é fundamental salientar que a escalada por si só não desenvolve os preceitos do habitus ambiental, mas sim, o contexto interacional envolvendo os diversos atores, a natureza e as demais atividades decorrentes desta interação.

Faz-se necessário que este tema seja cada vez mais discutido e que estudos sobre esta temática se multipliquem para que a sociedade compreenda que a natureza não é apenas um lugar de refúgio, mas um local essencial para nossa sobrevivência. Não somente a escalada é importante, mas todos os tipos de atividades realizadas na natureza levam a sociedade a ampliar a discussão sobre as questões ambientais. 
Novos estudos se fazem necessários para ampliar as discussões sobre esta prática e o potencial dela como uma atividade de lazer que proporciona benefícios não somente para a saúde e a construção de valores ambientais, mas como um espaço de interação para levar os praticantes a desenvolverem novos saberes a partir de experiências lúdicas na natureza e o potencial de novas atitudes que o contato com a natureza pode proporcionar à humanidade.

\section{REFERÊNCIAS}

ARAÚJO, H. R. de; OLIVEIRA JÚNIOR, A. F. de; AZEVEDO, A. A. "Valoração de serviços ambientais: subsídio para a sustentabilidade do atrativo natural gruta do salitre, Diamantina, Minas Gerais". Pesquisas em Turismo e Paisagens Cársticas, v. 8, n. 1, p. 17-26, 2015.

BAHIA, M. C.; SAMPAIO, T. M. V. Lazer - meio ambiente. Em busca das atitudes vivenciadas nos Esportes de aventura. Revista Brasileira de Ciências do Esporte, v. 28, n. 3, p. 173-189, 2007.

BARDIN, L. Análise de conteúdo. São Paulo: Edições 7 Persona, 2011.

BERTUZZI, R. et al. Fatores determinantes do desempenho na escalada esportiva: umas das contribuições da professora Maria Augusta Kiss para o desenvolvimento das ciências do esporte no Brasil. Revista Brasileira de Medicina do Esporte [online], v. 17, n. 2, p. 84-87, 2011.

; SILVA, A. E. L. Principais Características dos Estilos de Escalada em Rocha e Indoor. Revista Acta Brasileira do Movimento Humano. v. 3, n. 3, p. 31-46, 2013.

BETIOLLO, G. M.; SANTOS, S. S. Contribuições do montanhismo para a educação ambiental. Revista Motrivivência, v. 20, n. 21, p. 163-187, 2003.

BRASIL. Resolução $\mathbf{N}^{\mathbf{0}}$ 466, de 12 de dezembro de 2012. Disponível em: http://bvsms.saude.gov.br/bvs/saudelegis/cns/2013/res0466_12_12_2012.html. Acesso em: 20 jan. 2020.

BURITI, M. S. L. Variáveis que influenciam o comportamento agressivo de adolescentes nos esportes. In: BURITI, M. A. (org.). Psicologia do Esporte. Campinas: Editora Alínea, 2001.

COSTA, V. L. M. Esportes de aventura e risco calculado na montanha: um mergulho no imaginário. São Paulo: Manole, 2000.

COMUNELlO, L. N. Campo Ambiental, Habitus Ecológico e Aprendizagem Situada: contribuições para a Educação Ambiental. ANPED, 10, Sul, Florianópolis. Anais... outubro, p. 1-15, 2014. 
ENNES, M. Os fatores de risco real nas atividades de montanhismo. Cadernos UniFOA, v.21, n. 1, p. 37-52, 2013.

FALEIROS, F. et al. Uso de questionário online e divulgação virtual como estratégia de coleta de dados em estudos científicos. Texto Contexto Enfermagem, v. 25, n. 4, p. 2$6,2016$.

GOMES, C. L. Lazer: Necessidade Humana e Dimensão da Cultura. Revista Brasileira de Estudos do Lazer. Belo Horizonte, v. 1, n. 1, p. 3-20, jan/abr, 2014.

HONORATO, T.; XAVIER, E. Aspectos da Escalada para Formação Profissional em Educação Física. In: LORO, A. P.; VINHA, M.; GOLIN, C. H. (org.). Educação Física: Enfoques Contemporâneos. Dourados: Editora UFGD, 2013.

LOPES, C. Design de Ludicidade. Revista Entreideias, Salvador, v. 3, n. 2, p. 25-46, jul./dez. 2014.

MARINHO, A.; BRUHNS, H. T. Escalada urbana - faces de uma identidade cultural contemporânea. Revista Movimento, v. 7, n. 14, p. 37-48 2001.

NAZARI, J.; GOMES, A. C.; OLIVEIRA, T. C. Escalada: esporte e lazer, subsídios teóricos. EF Deportes Revista Digital, Buenos Aires, n. 117, fev., 2008.

PRADO, L. F. R. P. A escalada esportiva para socialização de jovens. Trabalho de Conclusão de curso em Licenciatura em Educação Física, Faculdade de Ciências da Educação e Saúde, Centro Universitário de Brasília, 2016.

PAIXÃO, J. A. Esporte de aventura como conteúdo possível nas aulas de educação física escolar. Revista Motrivivência, v. 29, v. 50, p. 170-182, 2018.

PEREIRA, D. W. Escalada. São Paulo: Odysseus Editora, 2007.

.; PICOLLO, V. L. N.A ética na escalada: uma análise a partir da complexidade de Edgar Morin. Revista Educação Física, v. 24, n. 1, p. 61-69, 2013.

SANTIN, S. Educação Física outros caminhos. 2. ed. Porto Alegre: EST / ESEF Escola Superior de Educação Física - UFRGS, 1993.

SILVA, S. L. P. Habitussócio-ambiental: elementos de compreensão da representação ambiental. Política e Trabalho - Revista de Ciências Sociais, n. 25, out., p. 225-237, 2006.

TAHARA, A. K.; CARNICELLI FILHO, S. Atividades físicas de aventura na natureza (AFAN) e academias de ginástica: motivos de aderência e benefícios advindos da prática. Revista Movimento, v. 15, n. 3, p. 187-208, 2009.

VARGAS, G. R., SILVA, D. S., AMARAL S. C. F. Participação em um Grupo de Escalada como uma Prática de Lazer. Revista Licere, Belo Horizonte, v. 18, n. 4, dez., 2015. DOI: doi.org/10.35699/1981-3171.2015.1158 


\section{Endereço dos autores:}

Ingrid Olegário Antas

R. Maria do Carmo Maia de Albuquerque, 65/102 -Gramame

João Pessoa - PB - 58.067-223

Endereço Eletrônico: ingrid_jp@live.com

Mateus David Finco

R. Bancário Waldemar de Mesquita Accioly, 440 / 203 - Bancários

João Pessoa - PB - 58.051-420

Endereço Eletrônico: mateus.finco@academico.ufpb.br 